\title{
Pesantren: the miniature of moderate Islam in Indonesia
}

\author{
Syamsun Ni'am \\ Faculty of Islamic Education, State Institute for Islamic Studies (IAIN), Jember \\ E-mail:niamstainjbr@gmail.com; ni_amstainjbr@yahoo.co.id
}

\begin{abstract}
Since reformation movement was trundled by students and people in Indonesia in 1998, all most thought and social movement domain are influenced by the reformation, primarily those relate to the religious understanding and its practice. At the time before reformation the people were in the quo status detention, who used to agree with all the uniformity of thought and movement-including in religious practice. However, in line with the reformation movement, the uniformity have been dissolved, so it encourages the emergence of various new religious thoughts. These have brought the consequences of emerging issues of islamic liberalism, funadamentalism, moderatism, ect. in Indonesia. The study of moderate Islam Indonesia have found the momentum to be seeked the roots of the devolopment in Pesantren.
\end{abstract}

Sejak gerakan reformasi digulirkan oleh para mahasiswa dan masyarakat Indonesia pada tahun 1998, seluruh pemikiran dan gerakan sosial telah terpengaruh olehnya, khususnya terkait dengan pemahaman dan praktek keberagamaan. Pada saat sebelum reformasi digulirkan, masyarakat Indonesia berada dalam tekanan status quo, di mana mereka sudah terbiasa hidup dalam keseragaman dalam pemikiran dan gerakan -termasuk di dalamnya adalah praktek keberagamaan. Akan tetapi, dengan digulirkannya gerakan reformasi tersebut, 
keseragaman (uniformitas) telah menjadi pudar, dan hal ini telah memunnculkan berbagai model pemikiran keagamaan yang baru. Hal ini telah membawa konsekuensi terhadap munculnya isu-isu tentang liberalisme, fundamentalisme, moderatisme, dan sebagainya di Indonesia. Kajian tentang Islam moderat di Indonesia ini telah menemukan momentumnya, untuk dicarikan dasar-dasar pengembangannya di pesantren.

Keywords: Learning Moderatism; Pesantren in Indonesia; Muhammadiyah; NU (Nahdlatul 'Ulama).

\section{Introduction}

Since the reform era in 1998, Indonesia seemed to be exposed to a myriad of problems which until now has not finished. Even it tends to develop from one problem to another. According to the author, the major problem comes from three main problems, which are interrelated and interconnected. First, the nationality problem concerned about the lack of sense of nationalism. This is evidenced by the national political process that runs for is no longer heed religious values and national-cultural principles that have crystallized and rooted in Indonesia since the state was founded. As a result, there is disharmony between pragmatic and practical demands of conscience itself. Pragmatic-practical demands are more dominant than the individual conscience demands that should promote fairness, justice, and welfare for the people (al-maslahat al'ammah).

Second, humanitarian problems are related with the lack of brotherhood as fellow children of the nation, identity loss as human beings should be respected and honored, loss of sense of community, sense of mutual cooperation, mutual help among others, recognition loss of the existence of the other, etc. The third problem is a religious problem related with religious understanding which is not comprehensive (kaffah); ${ }^{1}$, which

\footnotetext{
${ }^{1}$ Comprehensive is often synonymous with the term "käffah" in terms of the Qur'an. For example, in a piece of verse 208 in Sura al-Baqarah: ادخلوا فن السلم كافة "O you who believe,
} 
then has implications for the practice of exclusive religious and humanist, resulting in the emergence of what is understood justification by him alone, to deny even consider others who have different understanding do not deserve to live in this country.

Referring to the Report of the Wahid Institute (WI) 2008 and the Moderate Muslim Society (MMS) 2009, that religious conflicts tend to not be better. In the 2008-2009 annual report on religious pluralism, there are eight categories recorded by WI and MMS from 2008-2009: The deception of the group/individual, whether it is done by the community, the state, or a combination of both, Violence based on religion, Religious regulation, Places of worship conflicts, such as vandalism, licensing problems, land disputes and other matters related, Freedom of thought and expression, Inter-religious relations as the issue of the spread of hatred against other religions, Religious fatwa and Morality and pornography which, although not directly related to religion, but the issues of morality and pornography-in-praxis reality cannot be separated from religious understanding. ${ }^{2}$

This shows that Indonesia's long history of nationality has experienced ups and downs in building religious harmony and diversity. Therefore, the solution that would deserve serious attention is by controlling those aspects of cultural Islam moderates in Indonesia. Because cultural Islam in Indonesia grows and evolves with contextualization, accommodation

enter ye into the whole Muslim [comprehensive]). Comprehensive understanding of Islam in the group in part defined in accordance with the messages in the al-Quran and al-Hadith. But in the context of subsequent, comprehensive (kaffah) by some people have been elaborated in accordance with the understanding of the understanding itself. As a consequence, if it is found to be different from the understanding of the understanding, Islam is understood others considered comprehensive (käffah) as mentioned in the Qur'an.

${ }^{2}$ Detailed reports can be viewed on MMS, Laporan Akhir Tahun 2009 Toleransi dan Intoleransi di Indonesia, 6. 
and acculturation time and place. Thus, the characteristic of Indonesian Islam and those in Arab, Middle East, Afghanistan, etc are different.

\section{Moderate Islam ${ }^{3}$ in Indonesian history}

In the history of religion in Indonesia, Islam has developed quite unique. In terms of religion, such as the Javanese before accepting the influence of Hindu religion and culture, in its early stages was dynamistic and animistic. They worshiped the ancestor spirits, and believed in the power of magic or magical power contained in objects, plants, animals, and were considered to have magic power. Belief and worship as mentioned above, by itself not manifest itself as a real and conscious religion. ${ }^{4}$

${ }^{3}$ In 2008 Japan Institute of International Affairs (JIIA) held a symposium in Tokyo. The theme "Islam and Asia: Revisiting the Socio-Political Dimension of Islam", which is about the future of political Islam. Participants majority of Islamic countries such as Egypt, Pakistan, Iran, Turkey, Tunis, Indonesia and Malaysia, plus one from the U.S. and several of Japan itself. It seems that this symposium aims to measure the future of Muslim political power after the events of 11 September, will be in the hands of radical or moderate. Thus, among the issues raised about the meaning there is a moderate Muslim. This term seems to serve as a tamer of terrorism. Similar to the function of secularism in the 70's as a tamer fundamentalism. At first the participants responded with flat course. "Moderate" means no excessive ghuluw (extreme) in his religion. For Professor bedowi Abdelmajid from Tunis, the moderates in Islam is reflected in the faith, worship, social of affairs, and in the tradition of thought as well as in real life. But the problem becomes crucial when Angel Rabasa, representative of the Rand Corporation defines America, moderate Muslims are willing to accept pluralism, feminism and gender equality, democracy, humanism and civil society. Dr. Sohail Mahmud of Pakistan considers the definition Rabasa was loaded with Western interests. Azzam Tamimi, director of al-Hiwar TV London, rejected the definition and confirmed that the majority of Muslims according to Islamic criteria is moderate though not agree with pluralism, feminism, humanism, etc. See "Moderate" in http://insistnet.com/ index.php?option $=$ com_content $\&$ view $=$ article $\&$ catid $=$ moderate $2 \% 3$ Ahamidfahmyzarkasyi $=17$. There is also a moderate who interpret Islam as a violent antiIslam and anti-terrorism. Moderate Islam is identical with a friendly Islam, not extreme right and the extreme left. View Ahmad Najib Burhani, "Moderate Islam is a paradox," in http: //blog.uad.ac.id/latif_ilkom/ 2010/06/09/ islam-moderat-adalah-sebuah-paradoks.

${ }^{4}$ Simuh, Mistik Islam Kejawen Raden Ngabehi Ranggawarsita: Suatu Studi Terhadap Serat Wirid Hidayat Jati, Jakarta: UI-Press, 1988, 1. 
In such a religious level, the influence of original religion to Indonesia against new religions is real that can not be avoided. According to Seno Harbangan Siagian, every Indonesian however is advance, remain unaffected by the native religion more or less attached to his faith, whether he is a follower of Hinduism, Buddhism, Islam, and Christianity. ${ }^{5}$

Indonesian Native Religions, according Rachmat Subagya, were spiritual concepts in tribal communities that internally grow, develop, and reach perfection without imitation or external influences, resulting in the further development of religion-Islam-especially in Indonesia, has experienced ups and downs, as a sociological-psychological, the carriers and spreaders of Islam itself is required to understand the culture of the people of Indonesia are covered sincretisism. ${ }^{6}$

Among the historians, either from the West (orientalist) and East (Islam) there are many diverse views about the coming of Islam to Indonesia. It is a fact that Islam came to Indonesia in a peaceful manner (civil penetration), with no support from the government or the military campaign, the early determination of the arrival of Islam seem less significant because of the people involved in the first mission does not tend whatsoever, other than sense of responsibility to fulfill obligations unconditionally, so that their names go by swallowing history. Although it was discovered there are diverse views about the coming of Islam to Indonesia, the initial determination of the advent of Islam can be categorized into two perspectives. First, the view that assumes early arrival of Islam in

\footnotetext{
${ }^{5}$ Alwi Shihab, Islam Sufistik: Islam Pertama dan Implikasinya hingga Sekarang di Indonesia, Bandung: Mizan, 2001, ed. I, 1.

${ }^{6}$ Syncretism: The mingling together of different philosophies or religions, resulting in hybridforms of philosophy or religion. See Alan Richardson, Dictionary of Christian Theology, London: 1969, 331. Syncretism can also mean: A movement to bring about a harmony of positions in philosophy or theology which are somewhat opposed or different. Lihat edisi D.D. Runes, Dictionary of Philosophy, USA, tth., 308. See Simuh, Mistik Islam..., 2.
} 
the 7th century $\mathrm{AD} \mathrm{H} / 13$. Second, the view that embraces the first century $\mathrm{AH} .{ }^{?}$

In terms of the Islamization process in Indonesia, there are several theories as M. Solihin wrote. First, the theory that the history of Islam in Indonesia through economics-business (trading). ${ }^{8}$ The theory is quite reasonable, because Indonesia has long been established trade with the Arab nations, Gujarat and China. Second, the theory of marriage approaches, migrants and Muslim traders from the Middle East established kinship with the locals. From this marriage, it produced to a new generation of Muslims in Indonesia.

Third is the theory through political (power). The approach is political propaganda efforts undertaken by the merchants and Muslim immigrants, who managed to Islamize palaces of kings and princes, who had previously embraced Hinduism or Buddhism. This theory seems to hold true after the formation of Islamic kingdoms in the archipelago, which managed to Islamize neighbor kingdoms.

Fourth is the theory Sufi approach. This theory is also quite argumentative because the founding fathers were Islamic scholars who had the knowledge and experience of Sufi. They appear as a scholar who practiced sufis morals, even they often carry and practice specific congregation. The scholars appeared as charismatic Sufi figures, authoritative and wise, and being accommodating to the local culture, in addition to moderate, pluralist and inclusive, and always uphold the values of the noble ideals.

\footnotetext{
${ }^{7}$ In this regard, the argument is different from the arguments of each. More details can be seen on Shihab, Islam Sufistik..., 4-8.

${ }^{8}$ This can be evidenced by the reports of Marco Polo who visited the north shore of Sumatra who first embraced Islam in the Malay, the Chinese imperial envoy and affirm Islamic Sultanate of Samudra Pasai. Found here that traders from Kromendul and Arab traders from Baghdad after the fall of the Mongol attacks which spread Islam in Perlak, which later became part of the Kingdom of Aceh city. View Shihab, Islam Sufistik..., 4-5.
} 
Therefore, without denying the other three approaches, this last approach seems to be considered more acceptable because it is by looking at figure-bearers of Islam as mentioned above. Thus, it has been recognized by the orientalists, A.H. Johns admits that it is less possible when Islam came to Indonesia through trade approach. He put forward the theory that the Sufis travelers look more successfully spreading Islam in Indonesia.

Azyumardi Azra, in line with A.H. John above, that the success of the Sufi scholars are very visible when there are many Muslims including clerics and Sunni-Sufi-from Persia who migrated to new areas islamized due to the emergence of the uncertain political situation in the region. It can speed up the conversion to Islam, which is in the Indian subcontinent, Eastern Europe, Southeast Asia, and Indonesia in the period between the second half of the 10th century and, the end of the 13th century. The whole process has contributed to resurgence by Hodgson called the "internationalization" Sunni Islam. ${ }^{9}$

The process of the spread of Islam in the countries of Southeast Asia, especially in Indonesia, are growing spectacularly is a fact that can not be denied either by historians and researchers. This is because of the attitude shown by the Sufis was full of compassion, compromise, and more moderate-minded, pluralistic, and inclusive. Alwi Shihab added that it does have a tendency Sufism human-oriented open and cosmopolitan. ${ }^{10}$

The statement is no exaggeration; we have witnessed many Sufi leaders with their attitudes and behavior which are helpful, compassion, sense of togetherness and true brotherhood among the people, so it is not

${ }^{9}$ See Azyumardi Azra, Jaringan Ulama Timur Tengah dan Kepulauan Nusantara Abad XVII dan XVIII: Melacak Akar-akar Pembaruan Pemikiran Islam di Indonesia, Bandung: Mizan, 1998, Ed. IV, 36; M.G.S. Hodgson, The Venture of Islam II, Chicago: Universty of Chicago Press, 1974, 1-368.

${ }^{10}$ Shihab, Islam Sufistik..., 13. 
surprising that the Sufis were very close to people. This is why Islam spread rapidly in the country peacefully, without violence.

Abbas Mahmud al-Aqqad says the same thing that "perhaps the Indonesian archipelago is the most appropriate place to prove the fact that Islam is accepted and thrive in the midst of people who adhere to other religions. In every corner of the country there is evidence of how good exemplary role in spreading non-violent means". It is proved that the carrier and disseminator of Islam has been aware of the prevailing sociocultural and socio-psychological Indonesian society, so the approach and methods used were very suitable and preferred people of Indonesia.

The most influential Sufi figure in the history of Islamization in Indonesia is "Wali Songo". Activities and positive efforts, accommodating and moderate they do, look at all the expression author Madkhal ila al-Tarikh al-Islām bi al-Sharq al-Aqșā with the following illustration:

"Islam came to the islands was carried away by the noble morality, virtuous, wise men, and the spirit of hard work. Meanwhile, nations that receive their arrival have clear conscience, so that the joy of receiving the invitation and expressed their faith. They are the descendants of 'Ali and Fatima bint Muhammad set foot in areas that have not been touched by the hands of the West. They do it not with the army, but the spirit of faith, nor power, but an attitude of confidence and faith. They were armed with nothing but resignation; no motor boats, no army anyway; that they carry only the faith and the Koran. They managed to achieve that goal can not be achieved with all the thousands of troops and supplies complete facilities though, but they are only a few people”. Hadramaut region their home, the former moved the goal ashraf first generation. ${ }^{11}$

From among those born Imam Ahmad al-Muhajir, the pioneer ancestor propagation of Islam in Indonesia, religious ideas, schools, and con-

\footnotetext{
${ }^{11}$ See Abdullah ibn Nuh, al-Imām al-Muhājir, Jakarta: n.p., 1960, 93.
} 
ceptions of theology and the congregation is very influential in the lunge and struggle their descendants spread of Islam in Indonesia and surrounding islands. ${ }^{12}$ This is what later becomes the embryo of Sufi leaders-especially, in spreading the "Wali Songo"-known Sufi Islam accommodating and moderate in the archipelago. In further developments have inspired Islamic leaders archipelago in developing moderate Islam in Indonesia. Thus, by the "Wali Songo" Islam has been spread by peaceful means, not force others to convert followers of Islam, ongoing cultural respect, and even accommodate it into the local culture without losing its identity. Apparently tolerance is a lot of interesting people sympathetic to Indonesia at the time to follow the teachings of Islam.

Therefore, "Wali Songo" is a reliable architect in the grounding of Islam in Indonesia. According to records Abdurrahman Mas'ud, "Wali Songo" is a unique Java agents on the XV-XVI centuries were able to integrate the spiritual aspects of Islam and the secular in broadcasting. Their position in the socio-cultural and religious life in Java so compelling that it can be said Islam never be the religion of Java if Sufism developed by the "Wali Songo" is not rooted in society. Reference characteristics shows that Islam was introduced "Wali Songo" in Java comes with a peaceful, although seemed to slow but assured. Based on historical fact, that by tolerating the local traditions and modify it to the teachings of Islam and still rests on the principles of Islam, the new religion embraced by the aristocrats, and the majority of the people on the north coast of Java. ${ }^{13}$

Transmission Islam pioneered "Wali Songo" is a brilliant struggle that is implemented in a simple way, that show the way and new alternatives

\footnotetext{
${ }^{12}$ Shihab, Islam Sufistik..., 20-21.

${ }^{13}$ Miftahudin, "Islam Moderat Konteks Indonesia dalam Perspektif Historis", in http:/ / eprints.uny.ac.id/2407/9/ Akar_Islam_Moderat, p. 4-5. Accessed on March 11, 2012.
} 
that do not disturb the local traditions and customs, and easily captured by a layman because concrete approaches and realistic, meticulous, and united with social life. This model shows the uniqueness of Javanese mystics that are capable of absorbing elements of local and foreign culture, but at the same time, it still stands strong on the principles of Islam. ${ }^{14}$

Apparently "Wali Songo" were aware of how it should be grounded in Indonesian Islam. They understood that Islam should be contextualized, without losing the essence of the principles and teachings, in accordance with the conditions of the region or the world in which Islam spread. This is what became known as the concept of "indigenization of Islam". The idea is meant to melt the pattern and character of Islam as normative and religious practices into something contextual. In the "indigenization of Islam" illustrated how the normative teachings of Islam as derived from God accommodated to the culture derived from human without losing their identity. More concrete, contextualize Islamic teachings understood as related to the context of time and place. Change of time zone differences and a key to the work of interpretation and ijtihād. Thus, Islam will be able to continue to renew themselves and dynamically in response to changing times. Moreover, Islam is capable to dialogue with social conditions varying from one view to another angle. Adaptability is critical that in fact made Islam can truly adjust with time and place (suitable for every time and place).

This opinion is in accordance with the opinion of Quraish Shihab, stating that:

"Diversity is a necessity in life that is desired by God Almighty. This includes differences and diversity of opinion in the scientific field, even

${ }^{14}$ Abdurrahman Mas'ud, Dari Haramain ke Nusantara: Jejak Intelektual Arsitek Pesantren, Jakarta: Kencana, 2006, 67. 
the diversity of human responses concerning the truth of scriptures, interpretation of its contents, as well as the form of its practice." ${ }^{15}$

Fazlur Rahman asserted it, historically the main source of Islam is a divine revelation which then included in the book called the Koran. However, this book does not go down as well as the concurrent period, but down bit by bit and only collected after a few decades. Therefore, the revelation of this type is the reaction of the historical social conditions that took place at that time. The relationship between believers and revealed text made possible by the revelation that the normative aspect, while the pattern of the last run through the way of interpretation. The texts never speak for themselves, and it would be meaningless if associated with humans. What it was done, it was approved, and what is was said by the Apostle of Allah. It was the result of effort (ijtihäd) of the Messenger of Allah in understanding the normative dimensions of revelation. Meanwhile, the Apostle efforts to interprete the text were affected by the particular historical situation at the time. In fact, it was apostle of Allah Himself often changed its interpretation of the Koran if needed. ${ }^{16}$

The cultural plurality of the same religion can not be avoided when the religion has spread to vast areas with diverse cultural background. In the interaction and dialogue between religious teachings to local culture, the strength or weakness of the cultural roots of pre-existing by itself will determine how deep and strong the religious teachings of the universal reach of local socio-cultural realities. The plurality of religions face can also be caused by the different response of the followers of the same religion on social, cultural, and economic challenges they face. From the

${ }^{15}$ M. Quraish Shihab, Secercah Cahaya Ilahi: Hidup Bersama al-Qur'an, Bandung: Mizan, 2007, 52.

${ }^{16}$ Hendro Prasetyo, "Mengislamkan Orang Jawa: Antropologi Baru Islam Indonesia", in Islamika 3, (January-March 1994): 80. 
perspective of this is to be explained why, for example, the Islamist movement which is known as the "modernist" Muhammadiyah which tend to gain strong support in urban areas, while the NU (Nahdlatul 'Ulama) group often referred to as "traditional" gained widespread influence in the rural areas. ${ }^{17}$

So, the bottom line is that although the religion taught by the same prophet and holy book, but the religion is growing number of believers in the area of influence, the more difficult it will also face the unity of the faith can be maintained. Because, when the teachings and religions that come from heaven is about to land to plain empirical, then inevitably be faced with a series of socio-cultural realities that are often not appropriate or even contrary to religious teachings to be developed.

\section{Pesantren: ${ }^{18}$ Islamic miniature, Indonesian moderate}

Indonesian Moslems are Islam moderates as mentioned above, it is not difficult to find a reference in the history of Islam, both in itself and the origin of Islam in Indonesia. More precisely, Islam moderate can refer, if the area in which the coming of Islam, the practice of Islam of the Prophet Muhammad and his companions, in particular al-Khulafa ar-Rasyidun.

17 Pranowo, Islam Faktual..., 19.

${ }^{18}$ The word comes from the boarding students, which the prefix and suffix "pe" in front means the abode of the students. Professor Johns argued that the term comes from the Tamil students, which means a home tutor. Medium C.C. Berg argued that the term is derived from the term "shastri" which in India means a person who knows the sacred books of Hinduism, or an expert scholar of Hindu religious scriptures. The word comes from the word "shastri, shastra" which means holy books, religious books or books about science. See Zamakhsyari Dhofier, Tradisi Pesantren: Studi tentang Pandangan Hidup Kyai. Jakarta: LP3ES, 1994, 18. In this regard, Karel A. Steenbrink, argues that the traditional Islamic boarding schools are boarding schools in Indonesia. Teaching institution focused on religious instruction using traditional teaching methods and has the rules, administration, and curriculum teaching specialties. "Pesantren" usually led by a religious teacher or a scholar as well as teaching the students. For a more complete review, see Karel A. Steenbrink, Pesantren, Madrasah, dan Sekolah: Pendidikan Islam pada Periode Modern, Jakarta: LP3ES, 1994. 
Where the Prophet Muhammad had built cultural and social interactions are egalitarian with various groups at the time. After the Holy Prophet, the mission of prophetic là ilāha illälāah in Mecca, he went on his mission to move to the city of Medina, formerly known as Yathrib. Yathrib name used since the first came and built the city called Yathrib bin Amliq ibn Laudz ibn Nuh ibn Sham. Community Yathrib was quite diverse and familiar with pluralism. There were dominant tribes that inhabit the city, the tribe Aus, Khazraj, Qainuqa, Quraidlah, and Bani Nadzir. There were also very diverse religions, Muslims, Jews and Christians of Najran bit. In Islamic society itself, there are two kinds of groups, namely the migrants called immigrants (from some tribes of Mecca and its surroundings origin) and locals, which is called the Ansharin (which is dominated by the Aus and the Khazraj tribe). While more Jews came from the tribe Nadzir, Qainuqa, and Quraidlah.

Here the Holy Prophet had built civilization by the interactions and communication with various parties. The Prophet himself never applied discriminatory against any religions and groups there, including against Islam itself. He also built the foundations of the importance of ethical and moral foundation in establishing civilized people, who uphold the values of justice, liberty, equality of rights and obligations, as well as equal treatment under the law. To realize this then formed a "State of Medina". The concept is then laid out in "Sahififah Madinah (Medina Charter)" 19 which contains the basis of ethics and morality. The Holy Prophet (clear and unequivocal) had instilled the values of humanity, egalitarianism, mutual respect-inter-religious, inter-ethnic and tribal, as well as existing groups. ${ }^{20}$ Thus, the reasons and excuses whatsoever, any violence in the name was not found at its ethical foundation.

\footnotetext{
${ }^{19}$ Medina Charter consists of 47 Articles. See Ibn Hisham, Wustenfeld, 341-3; Watt, Medina, 22-5.

${ }^{20}$ Said Agil Siradj, Sufisme sebagai Kritik Sosial, Bandung: Mizan, 2006.
} 
Meanwhile, moderate understanding of Islam in the Indonesian context, can refer to the spreading of Islam known as "Wali Songo"-as previously described. Generation bearers of moderate Islam in Indonesia, just miniaturized, presumably to refer to the practice of Islam is done through organizations such as Muhammadiyah "a social and educational institution", and NU (Nahdatul 'Ulama) through education in their Pesantren. Islam in the Indonesian context of this kind more suited disclosed, to borrow the concept of Syafi'i Ma'arif, "Islam in Indonesian Frame”. Azyumardi Azra also often mentions that moderate Islam is the original character of religious Muslims in Indonesia. ${ }^{21}$

Pesantren as a miniature of the Indonesian Muslim community has shown their works in articulating moderate Islam in Indonesia. ${ }^{22}$ Moderate Islam style is then used as the basis in a friendly Islam spread to the universe. In this regard, there are some traditions that have long been demonstrated by Pesantren, where Pesantren is the oldest educational institution in the dynamic development of the history of Indonesia. Based on the results of a study conducted by observers, have shown that since the beginning of its development (early 16th century), Islamic mosque or the like kind, boarding, and other appropriate name preach Islam to the region-friendly and easy temperament with cultural heritage. As the oldest Islamic educational institutions, Pesantren have a major role in the process of Islamization (including cultural Islamization) in Indonesia, and even Southeast Asia. ${ }^{23}$

\footnotetext{
${ }^{21}$ See Ahmad Syafi'i Ma'arif, Islam dalam Bingkai Keindonesiaan dan Kemanusiaan; Sebuah Refleksi Sejarah, Bandung: Mizan, 2009.

${ }^{22}$ It cannot be denied it, that was allegedly found any schools that is far from moderatisme aspects. This then led to the emergence of irrelevant comments on the existence of pesantren. For example, Al-Mukmin Ngruki boarding Solo cared for by Ustadz Abu Bakar Bashir; Pesantren Al-Islam, in Tenggulun, Solokuro, Lamongan, East Java; Boarding School Umar bin Khattab, Bima, West Nusa Tenggara, and others. Even Yusuf Kalla as Vice President, had proposed to close the Islamic schools allegedly teach values violence.

${ }^{23}$ Basha, "Menelusuri Artikulasi...", 3.
} 
The ability of Pesantren with diverse cultural heritage characters is easy, and not oppressed with the progress of time, becomes sufficient evidence that the early history of Pesantren have stepped up and proceed openly to differences and diversity. Dissertation research field is quite interesting by Prof. Lukens-Bull (1997) from Arizona State University (ASU), USA Has supported this evidence, which Pesantren have managed to carve out a new identity. They rejected two forms of imitation such Kamal at-Taturk, and the rejection of Khomeini, against everything Western and modern versatile; Pesantren community are aware of and sensitive to globalization and Mc-Donalization, but remains actively respond to the globalization with jihād of peace education through Pesantren. ${ }^{24}$

According to historical records, the privilege has been achieved by Pesantren because it is supported by the presence of many Pesantren curriculum includes moderates and multiculturalism ideologies. It is often called the yellow book (classic referrences/kitab kuning), ${ }^{25}$ which until now is still a basic element of the curriculum of Pesantren.

${ }^{24}$ Masdar Farid Mas'udi, "Mengenal Pemikiran Kitab Kuning”, dalam Pergulatan Pesantren: Membangun dari Bawah, M. Dawam Rahardjo (ed). Jakarta: Perhimpunan Pengembangan Pesantren dan Masyarakat [P3M], 1985, 218.

${ }^{25}$ Yellow Book (Kitab Kuning) or commonly referred to as the classics are written works (Arabic) arranged medieval Islamic scholars (between 12-15 century AD), and is therefore often called the ancient book. The book though in terms of comprehensive abortion is said to be weighing academic, but in terms of the systematic presentation seems simple. For example, unknown reading signs as dots, commas, question marks, and so on. The shift from one sub-topic to other sub-topic, not to use or Alenia new paragraph, but with chapters or such similar code, tatimmah, muhimmah, tanbih, far', and so on. The content is presented in a yellow book is almost always made up of two components, namely the observations and other components are sharh\}. Matan is the core content will be removed by sharh. In its layout, matan placed outside the line of the rectangle that surrounds sharh\}. The other hand, is usually yellow book binding system with korasan (karasah), in which the sheet-sheet can be split so it allows the reader to explore it while relaxing or tetiduran, without having to carry all the books of the body, sometimes reaching hundreds of pages. In the meantime, why it was given the title of yellow, because the paper commonly used yellow, or white due to age, the color changed to yellow rose. See Masdar F. Mas'udi, "Mengenal Pemikiran”..., 55-56; See also Martin Van Bruinessen, Kitab Kuning, Pesantren dan Tarekat, 
Among the concrete example is the book of al-Milāl wa al-Niḥ̂al, written by al-Shahrastani $(479-485 \mathrm{H})$. The book review about firqah-firqah (factions) both within Islam and outside of Islam are presented objectively without any purpose insult or praise; book al-Figh al-Mazāhib al-Arba'ah (book four schools), written by al-Jazairi, to review the opinion of comparative fiqh scholars in the four schools. Of the two books, quite clearly the attitude of tolerance, respect for differences, and instilled the spirit of multiculturalism. ${ }^{26}$

Likewise indicated tafseer learned and studied at Pesantren. Anwār alTanzil wa Asrār al-Ta'wil by Abu Saìd al-Baidlāwì (d. 691 H/1191 M) and the book of Tafsir al-Jalāain -work of Jalāl al-Dīn al-Mahalli $(\mathrm{d} .864 \mathrm{H} /$ $1459 \mathrm{M}$ ) and Jalāl al-Dīn al-Suyūtị (d. $911 \mathrm{H} / 1505 \mathrm{M})$, in interpreting Qs. Yưnus verse 99. Jalālain said, "Do not (force you) to what Allah swt. do not want to do it for them! ". Al-Baidlawi also interpret, "Surely the difference desire/volition impossible equated to the force".

When interpreting the same verse, Ibn Kathir (d. 774 H/1373 M) in the Tafsir al-Qur'an al-Ažim stated, "(Hidāayah) what is that, but the affair of Allah." Shaykh al-Nawāwi al-Bantāni in Tafsir al-Munir said, "You do not have the power to change (belief) one. Faith can not be present in a person's life, unless the will of god (the will) and qudrah (power) of God".

Another example of the Qs. al-Nahl verse 125. Al-Baidlawi interpret this verse by saying, "Your duty is only to convey (the al-Balagh) and preach (al-da'wah). Medium guidance (al-Hidāyah) and apostasy (al-dalāl) it does not concern you. Allah Swt. better know who lost and who receive guid-

\footnotetext{
Bandung: Mizan, 1999, 142. however, in reality today, many books that are not yellow but white original, although the type and style of the book resembles the yellow book. However, most people still regarded as the yellow book without losing the characteristics, style and content.

${ }^{26}$ Syafiq Hashim, "Belajar Multikulturalisme dari Pesantren”, Al-Wasathiyyah Journal, Vol. 1, Number. 1 (February 2006), 66.
} 
ance. Allah swt who (right) they reply ". So that was shown by the books of classical commentators commonly studied in Pesantren.

According to K.H. Afifuddin Muhajir, the director of Ma'had Aly Sukorejo Situbondo in East Java, the teaching of figh is also full of moderation and tolerance. "Based on my reading, teaching tolerance is often found in the books of fiqh", he explained. Kyai Afif gave examples, such as a description of individual duty kifayah in the book Fath al-Mu'in -the work of Zain al-Din al-Malibārì (d. 975 H/1567 M) of Madzab Shäfi' 'i. AlMaTibäri explains, among social duty is kiswatu 'árin (giving clothes to the naked), including the dhimmi infidels. So, if a non-Muslim "dhimmis" is naked, social obligation duty for Muslims to give them clothes." 27

Kyai Afif gave another example; if Muslims and dhimmi infidels are together in a boat that is heavy load, so threatened to sink, then there must be stuffs on a boat that was sacrificed. This is for the sake of human safety, including safety infidel dhimmi's. Fiqh talk a lot of that way. There are many examples of the teachings of the tolerant and moderate in these classic books. There is also in the book of Tanbih al-Ghäfilin by Abu Layth al-Samarkandi (373 H/983 M). For example; it explained, "Muslims must be polite, kind to fellow Muslims, Jews, Christians, and the other believers." 28

The messages are displayed in classic Pesantren books in moderate frame in Indonesia -in fact- has been expressed by their sheikh. There are stories shown by K.H. Abdul Hamid Pasuruan, is known as a cleric who always accept and respect every guest that comes, even though other religions. Even just asking for prayer, Kyai Hamid was never refused. ${ }^{29}$

\footnotetext{
${ }^{27}$ See Ferdhi Gamal, Ragam Ekspresi Islam Nusantara, Jakarta: The Wahid Institute, Ed. I, 2008, 73-74.

${ }^{28}$ Ferdhi, Ragam Ekspresi..., 75.

${ }^{29}$ Details can be seen on Hamid Ahmad, Uswatun Hasanah: Biografi Keteladanan Kiai Hamid, Pasuruan: Yayasan Ma'had Salafiyah, 2001.
} 
Another example as shown by Kyai Achmad Siddiq; he quoted the Sufi perspective. According to Kyai Achmad, sufism can be embraced by all human beings without notice and differentiate ethnic origin, race, color, class, or religion. In Sufism, all being are considered equal. "We are all servants of God". Similarly, Kyai Achmad quoted the words of a Sufi. Kyai Achmad -in the discourse of Sufism -is well- regarded human beings, without any prejudices that are ideological, theological or discriminatory views, because humans are viewed equally. The differences of religion, tribe, race, skin color, only artificial distinction that should not hinder brotherhood among humans (ukhuwwah insāniyyah). ${ }^{30}$

Hence, the classic books are taught in Pesantren without a doubt largely dominated by the teachings of the tolerant and moderate in the order of human life. It seemed to be a refutation of the National Survey Findings: Attitudes Behaviour Religious Violence in Indonesia, conducted Centre of Islam and Society (PPIM) UIN Jakarta, July 2006. Among the findings is that the yellow book has the potential to encourage the teaching of violence between religions. However, Jajang Jahroni hastily dismissed on research findings, that the majority of the yellow book encourages violence. "Actually we are not researching the yellow book, but violence in the name of religion". Jajang commented.

According to Kyai Afif, "Ignorance is the main cause of the Muslims spreading violence against people of different faiths. That's because their learning is not complete. The deeper knowledge of one's religion, the more tolerant". The same phrase as stated by David Dakeke, Islamic researcher at George Washington University, USA, in the book of Islam, Fundamentalism and the Betrayal of Tradition (2004). Dakeke wrote,

${ }^{30}$ Munawar Fuad Noeh and Mastuki HS., Menghidupkan Ruh Pemikiran K.H. Achmad Siddiq, Jakarta: Logos, 1999, 83; Syamsun Ni'am, The Wisdom of K.H. Achmad Siddiq: Membumikan Tasawuf, Jakarta: Erlangga Press, 2009, 150-151. 
growing violence and Islamic fundamentalism are born from Islamic modernism by ignoring the intellectual treasures of classic and tradition. ${ }^{31}$

In this context, the discussion of the moderate Islamic discourse in Indonesia, particularly in Pesantren, has found the momentum. Because, as long as Islam is often interpreted as a single reality-not plural or multicultural. In fact, in Indonesia moderate Islam and the multicultural reality are very strong, both socio-historical and global (global-local). Locally, for example, Islam in Indonesia is divided by Clifford Geertz in trichotomy: santri, secular and the noble (abangan), or the dichotomy perspective Deliar Noer, namely traditional and modern Islam, and there are many other views as liberal, fundamental, moderate, radical and so on. In the socio-historical, the presence of Islam in Indonesia can not be separated from a multicultural context as can be read in the history of Islam in Indonesia carried by "Wali Songo". ${ }^{32}$

Thus, learning about Islam moderates is not new. It has been shown by at least Pesantren with systems and patterns of teaching that are full of moderate and multiculturalism values. Such conditions can be viewed not only through the process of teaching and learning, but also the materials or curriculum they teach. Pesantren -long observation and experience of the author- is always taught the value of morality to respect one another and respect among diverse, style and diversity that exist in human beings, both religious differences, customs, culture, and so on. This is then referred to "Pesantren tradition", which is the length of the dialogue and the struggle between Islamic doctrine and local traditions. In Pesantren, through the teachings of morality and mysticism (akhlāq) are delivered, has developed the teachings of the need for upholding the

\footnotetext{
${ }^{31}$ Ferdhi, Ragam Ekspresi..., 76.

${ }^{32}$ Choirul Fuad, "Mengkaji Ulang Islam Multikultural" http://islamlib.com, accessed on March 13, 2012.
} 
attitudes of tolerance (tasāmuh), moderate (tawāsuț) and being consistent and optimistic (ta'ādul and istiqāmah).

In the historical development of independence until the establishment of the Republic of Indonesia, Pesantren has instituted Pioneers and "Father of the Nation (Founding Fathers)". We can mention them such, K.H. Hashim Ash'ari and his son K.H.A. Wahid Hashim, K.H. Ahmad Dahlan, K.H. Mas Mansur, Prof. Kahar Muzakkar, Ki Bagus Hadikusumo, H. Agus Salim, Sutan Syahrir, HAMKA, and others. All of them were educated in Pesantren, which are not only competent in the religion field, as well as its commitment to defend the universal values of humanity, but also because of their strong leadership and the spirit of nationalism and nationality. ${ }^{33}$

Therefore, at the present time, people should be willing to live beyond the bulkhead ethnicity, culture, and religion. To organize a harmonious life, they are required to face the reality of pluralism. ${ }^{34}$ The concept of pluralism is already a constitutional philosophy of the world today. Although each state has different political idiom, ranging from composite society, culture of pluralism, the melting pot community, through unity in diversity. All those refer to the meaning, which is "the recognition of the existence of pluralism". ${ }^{35}$

${ }^{33}$ M. Syafii Anwar, "Islam dalam Bingkai Keindonesiaan dan Kemanusiaan; Sebuah Refleksi Sejarah", Al-Wasathiyyah Journal, Vol. 01, Number 1 (February 1, 2006), 4.

${ }^{34}$ The word "pluralism" is derived from the Latin, "Plures" which means a few (several) with the implications of diversity and difference, of in some (many), homogeneous. See Nurcholish Madjid, "Pluralisme Agama di Indonesia”, Ulumul Qur'an IV, Vol. 3 (1995), 62. 68.

${ }^{35}$ Different terms are essentially supports the same meaning, "pluralism", and the difference is occurred due to differences in countries applying earlier. United States typically use the term "melting pot society", Canada using "multi-culturalism community", India using "a composite society", and Indonesia using "Unity in Diversity". See Thoha Hamim, "Islam dan Hubungan Antar Umat Beragama" FORMA, Volume XXVI, Surabaya: Faculty Student Magazine. Ushuluddin IAIN Sunan Ampel, 2001, 2. 
Thus the plural values are necessity, the rule of God (Sunnatullah) that can not be changed, altered, resisted and denied. Anyone who tries to deny the law of cultural diversity, it will give rise to the phenomenon of turbulence that is everlasting. Perhaps because of this denial, so that conflicts always arise, not only locally, regionally, and nationally, but also globally (international).

\section{Conclusions}

From the above, it is important to record together as recommendation and solutions: Peter L. Berger (2003) offers two strategies to respond to the emergence of intolerance as a result of the currents of modernity and secularization, which was "religious revolution" and "subculture of religion". The first is how the clergy can transform society as a whole and present a model of modern religion, and the second is how our efforts to prevent outside influences that do not easily fit into the religion. Radical Islamic movements emerged as an understanding of religion that tend literally, narrow, black-and-white. This uunderstanding will easily lead the reader on a rigid religious attitude. Reading of religion can not be separated from its historical context. Understanding religion is dynamic. For this reason, the open reading will keep us from hostile attitudes.

There are several solutions that can be offered in response to the phenomenon of radicalism: First, presenting Islam as a universal teaching that provides direction for peace on earth. Second, there needs to be an effort to raise the action to reject violence and terrorism stance. This action involves all groups within religions who do not want such things. Terrorism is a form of harassment and violence in the name of religion and humanity. Third, it's time to grow a moderate religious character. Understanding the dynamics of life openly with receiving the plurality of the other which is outside the group. Moderate diversity will fade the 
polarization between fundamentalism and secularism in dealing with modernity and change. Islam which is in the middle (ummatan wasat\}an) will shape the Islamic character which is democratic, open, and rational.

Islam is also present to meet the call of humanity and peace. It is our duty to give a positive image of Islam that is humanist and anti-violence. Only a history will prove whether the religion is able to present their goals as how the way should be.

\section{Bibliography}

Ahmad, Hamid. Uswatun Hasanah: Biografi Keteladanan Kiai Hamid. Pasuruan: Yayasan Ma'had Salafiyah, 2001.

Anwar, M. Syafii. "Menggali Kearifan Pesantren untuk Multikulturalisme", AlWasathiyyah, Vol. 01, Number. 01 (Februari 2006).

Al-Aqqad, Abbas Mahmud. al-Islām fi al-Qarn al-'Isyrin: Hädirihi wa Mustaqbalihì. Kairo: Dār al-Kutub al-Hadithah, 1954.

Arnold, T.W. The Preacing of Islam. London: 1935.

'Aun, Faisal Badr. al-Tashawuf al-Istāmi al-Täriq wa al-Rijāl. Kairo: Maktab Sa`ìd Ra'fat, 1983.

Azra, Azyumardi. Jaringan Ulama Timur Tengah dan Kepulauan Nusantara Abad XVII dan XVIII: Melacak Akar-akar Pembaruan Pemikiran Islam di Indonesia. Bandung: Mizan, 1998, Cet. IV.

Basya, M. Hilaly. "Menelusuri Artikulasi Islam Moderat di Indonesia", http:/ /www.madina-sk.com/index.php?option=com, diakses tanggal 15 Maret 2012.

Bruinessen, Martin Van. Kitab Kuning, Pesantren dan Tarekat. Bandung: Mizan, 1999.

Dhofier, Zamakhsyari. Tradisi Pesantren: Studi tentang Pandangan Hidup Kyai. Jakarta: LP3ES, 1994.

Ferdhi, Gamal. Ragam Ekspresi Islam Nusantara. Jakarta: The Wahid Institute, Cet. I, 2008.

Fuad, Choirul. "Mengkaji Ulang Islam Multikultural", http://islamlib.com, diakses pada 13 Maret 2012.

Gibb, H. A. R. Modern Trends in Islam. Chicago: 1945.

Hamim, Thoha. "Islam dan Hubungan Antar Umat Beragama", FORMA, Surabaya: Majalah Mahasiswa Fak. Ushuluddin IAIN Sunan Ampel, 2001, Volume XXVI. 
Hasyim, Syafiq. "Belajar Multikulturalisme dari Pesantren”, Jurnal AlWasathiyyah, Vol. 1, No. 1, Februari 2006.

Hisyam, Ibnu, Wustenfeld, 341-3; Watt, Medina, 22-5.

Hodgson, M.G.S. The Venture of Islam II. Chicago: Universty of Chicago Press, 1974.

Ma'arif, Ahmad Syafi'i. Islam dalam Bingkai Keindonesiaan dan Kemanusiaan; Sebuah Refleksi Sejarah. Bandung: Mizan, 2009.

Madjid, Nurcholish. "Pluralisme Agama di Indonesia”, 'Ulumul Qur'an, IV (3), 1995.

Mas'ud, Abdurrahman. Dari Haramain ke Nusantara: Jejak Intelektual Arsitek Pesantren. Jakarta: Kencana, 2006.

Mas'udi, Masdar Farid. "Mengenal Pemikiran Kitab Kuning", dalam Pergulatan Pesantren: Membangun dari Bawah. M. Dawam Rahardjo (ed), Jakarta: Perhimpunan Pengembangan Pesantren dan Masyarakat (P3M), 1985.

Miftahudin. "Islam Moderat Konteks Indonesia dalam Perspektif Historis", http://eprints.uny.ac.id/2407/9/Akar_Islam_Moderat, diakses pada tanggal 11 Maret 2012.

Moderat Muslim Society (MMS). Laporan Akhir Tahun 2009 Toleransi dan Intoleransi di Indonesia.

Ni'am, Syamsun. The Wisdom of K.H. Achmad Siddiq: Membumikan Tasawuf. Jakarta: Erlangga Press, 2009.

Noeh, Munawar Fuad dan Mastuki HS. Menghidupkan Ruh Pemikiran K.H. Achmad Siddiq. Jakarta: Logos, 1999.

Nuh, Abdullah ibn. al-Imām al-Muhājir. Jakarta: 1960.

Pranowo, Bambang. Islam Faktual: Antara Tradisi dan Relasi Kuasa. Yogyakarta: Adicita, 1999.

Prasetyo, Hendro. "Mengislamkan Orang Jawa: Antropologi Baru Islam Indonesia", Islamika Number.3, (Januari-Maret 1994).

Richardson, Alan. Dictionary of Christian Theology. London: 1969.

Runes, D.D. Dictionary of Philosophy. U.S.A: n.a.

Shihab, Alwi. Islam Inklusif: Menuju Sikap Terbuka dalam Beragama. Bandung: Mizan, 1997.

Shihab, Alwi. Islam Sufistik: "Islam Pertama" dan Pengaruhnya hingga Kini di Indonesia. Bandung: Mizan, 2001, Cet. I.

Shihab, M. Quraish. Secercah Cahaya Ilahi: Hidup Bersama Al-Qur'an. Bandung: Mizan, 2007.

Simuh. Mistik Islam Kejawen Raden Ngabehi Ranggawarsita: Suatu Studi Terhadap Serat Wirid Hidayat Jati. Jakarta: UI-Press, 1988. 
IJIMS, Indonesian Journal of Islam and Muslim Societies, Volume 5, Number 1, June 2015: 111-134

Siradj, Said Agiel. “Tradisi dan Reformasi Keagamaan”, Republika, 2 Juni 2007. Siradj, Said Agil. Tasawuf sebagai Kritik Sosial. Bandung: Mizan, 2006.

Solihin, M. Sejarah dan Pemikiran Tasawuf di Indonesia. Bandung: Pustaka Setia, 2001, Cet. I.

Steenbrink, Karel A. Pesantren, Madrasah, dan Sekolah: Pendidikan Islam dalam Kurun Moderen. Jakarta: LP3ES, 1994.

Subagya, Rachmat. Kepercayaan Kebatinan, Kerohanian, dan Agama. Jakarta: Yayasan Kanisius, 1970.

Tjandrasasmita, Uka. "Proses Kedatangan Islam dan Munculnya Kerajaankerajaan Islam di Aceh”, A. Hasymi (Ed.). Sejarah Masuk dan Berkembangnya Islam di Indonesia. Bandung: Alma'arif, 1993. 